\title{
ANALISIS HUKUM PENGHAPUSAN MEREK IKEA
}

\author{
Oleh: \\ Nur Febry Rahmadhiani* dan Catharina Ria Budiningsih** \\ * Alumni Fakultas Hukum Universitas Parahyangan \\ ‘** Dosen Fakultas Hukum Universitas Parahyangan \\ budiningsihria@gmail.com
}

\begin{abstract}
Trademarks have important functions for their owners, especially in the global trading era. Trademarks give indication of the origin and the quality of the traded goods or services. Trademark owners have the exclusive rights to authorize or prohibit others from using the same or similar marks with their own. Indonesia using a constitutive registration system, namely an exclusive right is granted for a registered trademark. A trademark applicant may not register the same mark with another person's well-known trademarks. A registered trademark must be used. Annulment of a trademark is done when the mark is not used for three consecutive years. Supreme Court Decision No.264 K/Pdt.Sus-HKI/2015 which held that IKEA owned by Inter IKEA System was annulled and the registration of ikea owned by PT RataniaKhatulistiwa was valid. The result of normative analysis on the case showed that the annulment of Inter IKEA System trademark and the validity of trademark application by PT RataniaKhatulistiwa did not automatically recognize the ownership of Ikea by PT RataniaKhatulistiwa. Judge verdict resulted Inter IKEA System's right to be excluded from trademark registration system so as allowing anyone to register the Ikea trademark. PT RataniaKhatulistiwa has exclusive rights if the application has passed the registration procedure and has a trademark certificate. If Inter IKEA System wishes to defend the same trademark,it must file an objection to the Directorate General of Intellectual Property and file a cancellation of the new trademark owner in court. If it has not succeeded it can still appeal and re-register. In general, trademark annulment occurs when a trademark is not used in the trade in goods and services. If the old owner still wants the same trademark rights, it must apply for a trademark registration and follow the entire registration procedure. If another party has first filed a trademark application, the former owner may file an objection. If this attempt fails, he may file a cancellation to the Commercial Court, the cassation, and a court review. It is recommended that the registered trademark owners use their registered trademarks. Long roads must be taken if the trademark rights is removed because it is not in use but the owner still wants the trademark rights.
\end{abstract}

Kata kunci: merek, hak eksklusif, sistemkonstitutif, penghapusan merek.

\section{A. PENDAHULUAN}

\section{Latar Belakang}

Kemajuan dunia perdagangan, baik dalam skala nasional maupun internasional, membuat para pelaku bisnis semakin memperhatikan objek perdagangan mereka. Apalagi di era globalisasi ketika arus barang berputar sangat cepat dan luas. Merek menunjukkan asal dan kualitas produk dan jasa yang diperdagangkan. Denganmengetahui asal dari suatu barang/jasa, masyarakat dapat menilai bagaimana kualitas produk yang akan dibeli. Kecenderungan masyarakat untuk membeli barang berdasarkan merek yang terdapat pada barang/jasa yang diperdagangkan memperlihatkan nilai ekonomis dari merek. Hal ini menyebabkan pelaku usaha sangat memperhatikan penggunaan merek dalam kegiatan bisnis. Merek merupakan identitas pada perdagangan barang atau jasa.Nilai ekonomis ini timbul dari hak eksklusif yang dimiliki para pemegang hak atas merek. Hak eksklusif atas 
merek diberikan terhadap merek yang sudah terdaftar. Hak eksklusif atas merek menyebabkan pemillik merek memiliki hak ntuk meberikan ijin atau melarang pihak lain menggunakan merek yang sama atau pada pokoknya sama dengan merek yang ia miliki.

Salah satu aspek yang dilindungi dalam merek adalah perlindungan terhadap merek terkenal. Merek terkenal perlu mendapat perlindungan antara lain agar orang lain tidak membonceng reputasi merek milik orang lain yang sudah diketahui oleh khalayak ramai. Apabila merek terkenal digunakan oleh orang lain yang tidak bertanggungjawab, reputasi dari merek tersebut akan menjadi turun, karena di masyarakat beredar barang yang berkualitas bersama-sama dengan barang yang tidak berkualitas.

Merek-merek terkenal adalah merek-merek yang mempunyai reputasi yang tinggi dalam dunia perdagangan yang diakui secara internasional atau setidak-tidaknya secara regional. ${ }^{1}$ Kriteria merek terkenal selain memerhatikan pengetahuan umum masyarakat, juga didasarkan pada reputasi merek tersebut yang diperoleh karenapromosi dan telah dibuktikan dengan pendaftaran. ${ }^{2}$

Penggunaan merek terkenal milik orang lain pada dasarnya dilakukan dengan itikad tidak baik, karena pemakai tidak sah tersebut dapat memperoleh keuntungan dari ketenaran merek tersebut. Pengguna yang tidak bertanggung jawab memperoleh keuntungan dari kecenderungan konsumen membeli barang/jasa yang disangka berkualitas baik karena menggunakan merek terkenal.

Di dalam Undang-Undang Merek yang berlaku di Indonesia, baik Undang-Undang No. 20 Tahun 2016 maupun (eks) Undang-Undang No.15 Tahun 2001, tidak disebutkan definisi mengenai merek terkenal. Hak eksklusif atas merek diperoleh elalui pendaftaran Namun tidak semua hal dapat didaftarkan sebagai merek.Salah satunya terhadap merek yang memiliki persamaan pada pokoknya maupun keseluruhannya dengan merek terkenal, permohonannya harus ditolak. ${ }^{3} \mathrm{Hal}$ tersebut menunjukan bahwa terdapat perlindungan merek merek terkenal

Merek yang sudah terdaftar di Indonesia, harus digunakan. Berdasarkan Pasal 61 ayat (2) huruf aUU No. 15 tahun 2001 (sekarang Pasal 74 ayat (1) UU No. 20 tahun 2016), merek dapat dihapuskan jika selama 3 (tiga) tahun berturut-turut tidak digunakan dalam perdagangan barang dan/atau jasa sejak tanggal pendaftaran atau pemakaian terakhir.

\footnotetext{
Suyud Margono, Hak Milik Industri Pengaturan Dan Praktik di Indonesia 107, Ghalia Indonesia, Bogor, 2011, Hlm 107.

2 Muhammad Djumhana \& Djubaedillah, Hak Milik Intelektual: Sejarah, Teori dan Praktiknya di Indonesia, Citra Aditya Bakti, Bandung, 2014. Hlm. 228.

3 Lihat Pasal 6 angka (1) huruf b UU No. 15 tahun 2001 dan Pasal 21 ayat (1) huruf a dan b UU No. 20 tahun 2016.
} 
Pada tulisan ini dilakukan analisis terhadap kasus dan putusan pengadilan mengenai penghapusan merek "IKEA". Di dalam kasus tersebut, merek "IKEA" milik Inter IKEA System dihapus melalui putusan pengadilan karena merek "IKEA" tidak digunakan selama 3 (tiga) tahun berturut-turut.

Kasus ini bermula ketika PT.Ratania Khatulistiwa sebuah perusahaan Surabaya hendak menggunakan merek "ikea" terhadap barang-barang produksinya. Untuk memperoleh hak atas merek "ikea", PT. Ratania Khatulistiwa mengajukan gugatan penghapusan merek "IKEA" ke Pengadilan Niaga Jakarta Pusat untuk kelas $20^{4}$ dan $21^{5}$. Dalam putusannya, Pengadilan Niaga Jakarta Pusat mengabulkan gugatan PT. Ratania dengan menghapus merek "IKEA" milik Inter IKEA System dan menyatakan sahnya permohonan pendaftaran merek"ikea" milik Inter IKEA System. Putusan Pengadilan Niaga Jakarta Pusat itupun diperkuat melalui Putusan Mahkamah Agung.

\section{Rumusan Masalah}

a. Apakah dengan adanya putusan pengadilan tersebut,merek "IKEA" yang dimiliki Inter IKEA System berakhir, sertaotomatis menyebabkan PT. Ratania Khatulistiwa memiliki hak eksklusif atas "ikea” menggantikan Inter IKEA System;?

b. Apakah yang harus dilakukan, jika pemilik merek yang mereknya dihapuskan berdasarkan putusan pengadilan masih mengharapkan hak eksklusif atas merek yang dihapuskan tersebut?

\section{Metode Penelitian}

Pendekatan utama dalam penelitian pada makalah ini adalah yuridis normatif, dengan melakukan studi kepustakaan. Bahan hukum primer yang digunakan adalah Undang-Undang tentang Merek (Undang-Undang No.20 Tahun 2016 dan UndangUndang No.15 Tahun 2001). Sumber sekunder yang digunakan adalah Putusan Pengadilan Niaga No.99/PDT.SUS-MEREK/2013/PN. Niaga.Jkt.Pst tertanggal 17 September 2014 dan Putusan Mahkamah Agung No.264 K/Pdt.Sus-HKI/2015

\footnotetext{
Klasifikasi Barang Kelas 20: Perabot rumah, kaca, bingkai; benda-benda (tidak termasuk dalam kelas lain) dari kayu, gabus, rumput, bambu, rotan, tanduk, tulang, gading, tulang ikan paus, kerang, amber, kulit mutiara, selloid dan dari bahan-bahan penggantinya, atau dari plastik. Dikutip dari http://skm.dgip.go.id/index.php/skm/detailkelas/20 pada 10 Agustus 2017 pukul 11.14 WIB

5 Klasifikasi Barang Kelas 21: Perkakas rumah tanggal atau dapur dan wadah kecil (bukan darii logam mulia atau bukan sepuhan logam mulia); sisir dan bunga karang; sikat (kecuali kuas melukis); bahan-bahan pembuatan sikat; perkakas dan alat untuk membersihkan; kulit besi untuk menggosok; kaca yang belum dikerjakan atau dikerjakan sebagian (kecuali kaca yang disunakan dalam gedung); barang pecah belah,porselin dan barang-barang tembikar tidak termasuk dalam kelas lain. Dikutip dari http://skm.dgip.go.id/index.php/skm/detailkelas/21 pada 10 Agustus 2017 pukul 11.18 WIB
} 
tertanggal 12 Mei 2015, serta buku-buku dan jurnal yang berkaitan dengan topik makalah.

\section{B. PEMBAHASAN}

1. Merek "IKEA" yang dimiliki Inter IKEA System berakhir, serta otomatis menyebabkan PT. Ratania Khatulistiwa memiliki hak eksklusif atas "ikea" menggantikan Inter IKEA System.

Merek adalah suatu tanda (sign) untuk membedakan barang-barang atau jasa yang sejenis yang dihasilkan atau diperdagangkan seseorang atau kelompok orang atau badan hukum dengan barang-barang atau sejenis yang dihasilkan oleh orang lain, yang memiliki daya pembeda maupun sebagai jaminan atas mutunya dan digunakan dalam kegiatan perdagangan barang atau jasa. ${ }^{6}$ Tanda tersebut dapat berupa kata, huruf, angka, gambar, bentuk dan warna, juga kombinasinya. ${ }^{7}$ Schecher dan Thomas mendifinisikan merek sebagai berikut: "As a device used by a merchant to identify its goods or sevices and to distinguish them from those of others" ${ }^{8}$ Sementara itu Colston menyebutkan dua fungsi utama merek sebagai berikut: "first, to provide an indication of source and, secondly, to guarantee quality. Both these functions can be isolated in a mark's caapacity to distinguish". 9

Sedangkan menurut hemat penulis, merek dapat didefinisikan sebagai tanda untuk membedakan barang atau jasa yang diproduksi oleh pihak tertentu dengan pihak lainnya, yang dimana tanda tersebut hanya dapat digunakan oleh pemiliknya kecuali diperjanjikan lain, dan atas tanda tersebut diberikan hak eksklusif oleh Negara berupa perlindungan dalam jangka waktu tertentu.

Terdapat 2 (dua) sistem untuk memperoleh hak atas merek, yaitu Sistem Deklaratif dan Sistem Konstitutif.

Bagi negara yang menganut sistem deklaratif, perlindungan terhadap merek diberikan kepada mereka yang menggunakan merek tersebut pertama kali. Dalam sistem ini, pendaftaran merek tidak diwajibkan. Setiap orang bebas untuk mendaftarkan atau tidak merek yang akan digunakannya. Pemilik merek berhak menggunakan mereknya dan

OK Saidin, Aspek Hukum Hak Kekayaan Intelektual (Intellectual Property Rights, Rajawali Pers, Jakarta, 2015. Hlm .457 .

7 World Intellectual Property Organization, Memahami Hak Kekayaan Intellctual Industri, Direktorat Jenderal Hak Kekayaan Intelektual, penerj., World Intellectal Property Organization, Geneva, s.a, Hlm. 12.

8 Roger E. Schechter \& John R. Thomas, Intellectual Property The Law of Copyrights, Patents and Trademarks 359, Thomson-West, USA, 2003.

9 Catherine Colston, Princiles Of Intellectual Property Law, Cavendish Publishing Limited, London.Sydney, 1999, Hlm. 346. 
berhak atas hak eksklusif merek tersebut sepanjang ia bisa membuktikan bahwa ia adalah pemakai pertama merek tersebut.

Sedangkan dalam sistem konstitutif, hak eksklusif atas merek diberikan kepadamereka yang mendafarkan mereknya untuk pertama kali dalam Daftar Umum Merek. Sistem ini dinilai lebih menjamin kepastian hukum bagi pemilik merek dibandingkan dengan sistem deklaratif. Untuk pembuktian, tentunya sistem konstitutif lebih mudah dari pada sistem deklaratif.

Berdasarkan eks Pasal 3 UU No.15 Tahun 2001:

"Hak atas Merek adalah hak eksklusif yang diberikan oleh Negara kepada pemilik Merek yang terdaftar dalam Daftar Umum Merek untuk jangka waktu tertentu dengan menggunakan sendiri Merek tersebut atau memberikan izin kepada pihak lain untuk menggunakannya."

Dapat dilihat bahwa Indonesia menganut sistem konstitutif yang mengharuskan suatu merek didaftarkan agar memperoleh hak eksklusif. Setelah berlakunya UU No.20 Tahun 2016, Indonesia tetap menganut sistem pendaftaran merek yang sama. Hal ini dapat dilihat dalam Pasal 1 angka (5) yang berbunyi:

"Hak atas Merek adalah hak eksklusif yang diberikan oleh negara kepada pemilik Merek yang terdaftar untuk jangka waktu tertentu dengan menggunakan sendiri Merek tersebut atau memberikan izin kepada pihak lain untuk menggunakannya."

Serta dapat pula dilihat dalam Pasal 3, yaitu: "Hak atas Merek diperoleh setelah Merek tersebut terdaftar."

Untuk menentukan suatu merek bisa memperoleh perlindungan, Negara cq. Kementerian Hukum dan HAM cq. Direktorat Jenderal Kekayaan Intelektual cq. Direktorat Merek dan Indikasi Geografis (selanjutnya disebut Menteri), akan melakukan pemeriksaan terhadap merek yang dimohonkan pendaftarannya. Terdapat perbedaan alur pendaftaran merek sebagaimana yang diatur dalam (eks) UU No.15Tahun 2001 dengan UU No.20 Tahun 2016. Dalam (eks) UU No.15 Tahun 2001, pengumuman dalam Berita Resmi Merek dilakukan setelah pemeriksaan administratif dan substantif. Maka apabila terdapat keberatan dan sanggahan, dilakukan Pemeriksaan Kembali oleh Ditjen KI sehingga membutuhkan waktu yang lebih lama lagi.

Setelah UU No.20 Tahun 2016 diundangkan, alur pendaftaran merek lebih sederhana agar tidak memakan waktu yang lama. Pengumuman permohonan pendaftaran merek 
dilakukan sebelum pemeriksaan substantif. Jadi apabila terdapat keberatan dan sanggahan, akan diperiksa bersamaan pada saat pemeriksaan substantif.

Berikut alur permohonan pendaftaran merek, sebagaimana terdapat dalam UU No.20 Tahun 2016 dan UU No.15 Tahun 2001:

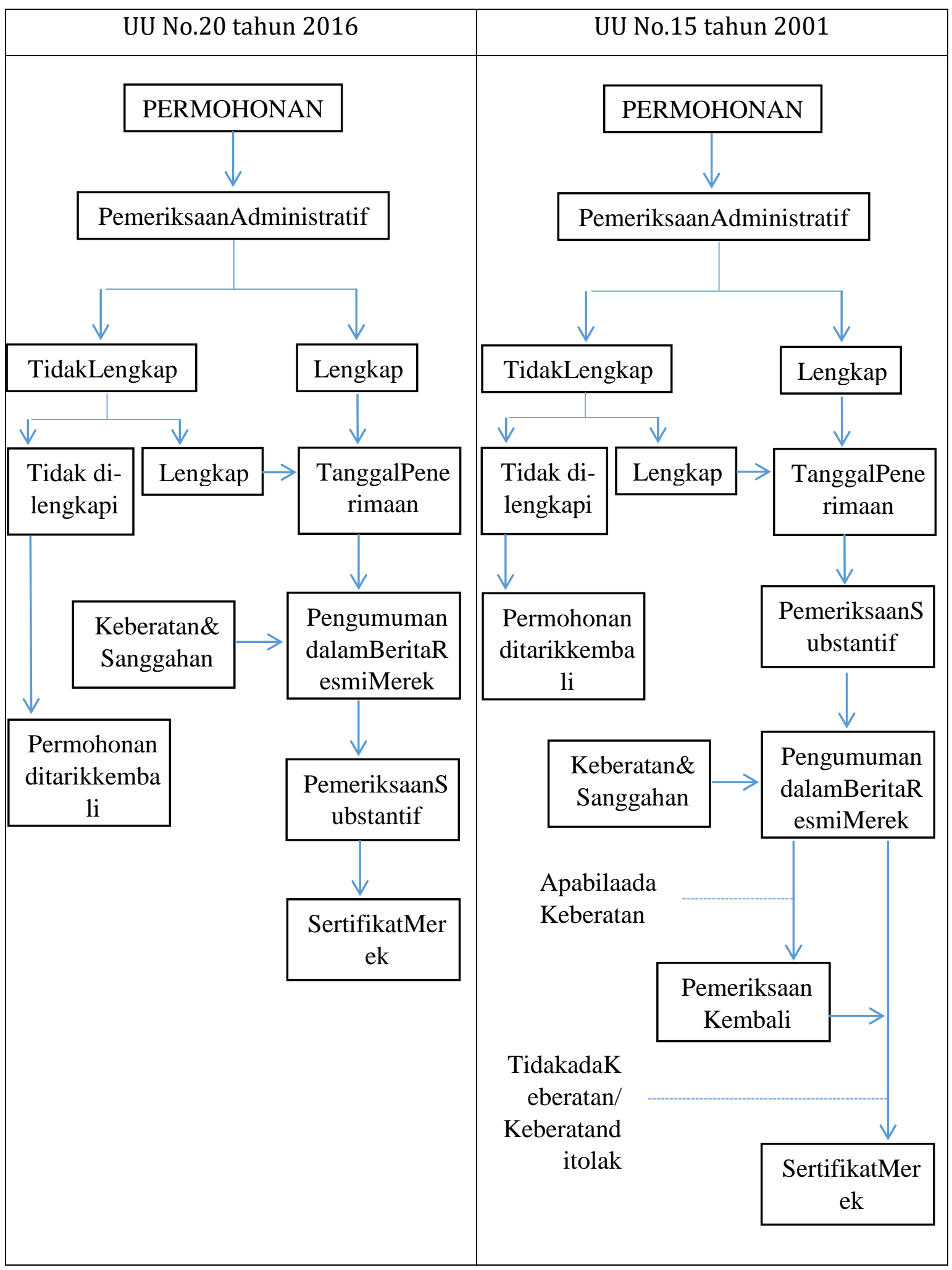


Dapat dilihat bahwa proses pendaftaran merek berdasarkan UU No.20 Tahun 2016 lebih sederhana daripada UU No.15 Tahun 2001.

Merek-merek terkenal adalah merek-merek yang mempunyai reputasi yang tinggi dalam dunia perdagangan yang diakui secara internasional atau setidak-tidaknya secara regional. ${ }^{10}$ Adapun yang menjadi ciri dari merek terkenal secara universal adalah: ${ }^{11}$

a) merek telah dipromosikan secara luas oleh pemiliknya sehingga menjadi terkenal luas di lingkungan bisnis dan konsumen;

b) bermutu baik dan banyak digemari oleh masyarakat konsumen;

c) tidak dapat didaftar oleh orang lain yang bukan pemilik merek tersebut (baik untuk barang/jasa sejenis maupun barang/jasa tidak sejenis).

Berdasarkan hukum positif Indonesia, pengertian merek terkenal tidak diatur, baik didalam (eks)Undang-Undang No.15 Tahun 2001 maupun Undang-Undang No.20 Tahun 2016.Untuk menentukan apakah suatu dapat merek tergolong sebagai merek terkenal atau tidak beberapa ketentuan di bawah ini dapat dijadikan acuan.

Di dalam Penjelasan (eks) Undang-Undang No.5 Tahun 2001 disebutkan: ${ }^{12}$

"Merek terkenal untuk barang dan/atau jasa yang sejenis dilakukan dengan memperhatikan pengetahuan umum masyarakat mengenai Merek tersebut di bidang usaha yang bersangkutan. Di samping itu diperhatikan pula reputasi Merek terkenal yang diperoleh karena promosi yang gencar dan besar-besaran, investasi di beberapa negara di dunia yang dilakukan oleh pemiliknya dan disertai bukti pendaftaran Merek tersebut di beberapa negara. Apabila hal-hal di atas belum dianggap cukup, Pengadilan Niaga dapat memerintahkan lembaga yang bersifat mandiri untu melakukan survei guna memperoleh kesimpulan mengenai terkenal atau tidaknya Merek yang menjadi dasar penolakan." yakni: ${ }^{13}$

Dalam Penjelasan Undang-Undang No.20 Tahun 2016 disebutkan hal serupa,

"Penolakan Permohonan yang mempunyai persamaan pada pokoknya atau keseluruhan dengan Merek terkenal milik pihak lain untuk barang dan/atau jasa yang sejenis dilakukan dengan memperhatikan pengetahuan umum masyarakat mengenai Merek tersebut di bidang usaha yang bersangkutan. Di samping itu, diperhatikan pula reputasi Merek tersebut yang diperoleh karena promosi yang gencar dan besar-besaran, investasi

Suyud Margono, Hak Milik Industri Pengaturan Dan Praktik di Indonesia, Ghalia Indonesia, Bogor, 2011, Hlm. 107. Ibid. Pada 101.

12 Lihat Penjelasan Pasal 6 ayat (1) huruf b (eks) Undang Undang No.15 Tahun 2001 Tentang Merek. Aturan ini masih disebutkan karena pada kasus yang dianalisis - kasus IKEA- dasar hukum yang digunakan masih (eks) UndangUndang No. 15 Tahun 2001 Tentang Merek.

13 Lihat Penjelasan Pasal 21 Ayat (1) huruf b, UU No.20 tahun 2016. 
di beberapa negara di dunia yang dilakukan oleh pemiliknya, dan disertai bukti pendaftaran Merek dimaksud di beberapa negara. Jika hal tersebut belum dianggap cukup, Pengadilan Niaga dapat memerintahkan lembaga yang bersifat mandiri untuk melakukan survei guna memperoleh kesimpulan mengenai terkenal atau tidaknya Merek yang menjadi dasar penolakan.”

Perhatian negara terhadap keberadaan merek terkenal secara normatif sudah dicantumkan dalam Keputusan Menteri Kehakiman Nomor M.03-HC.02.01 Tahun 1991 tentang Penolakan Permohonan Pendaftaran Merek Terkenal atau Merek yang Mirip Merek Terkenal Milik Orang Lain atau Milik Badan Lain. Disebutkan pada Keputusan Menteri Kehakiman tersebut: ${ }^{14}$

"Yang dimaksud dengan merek terkenal dalam keputusan ini adalah merek dagang yang secara umum telah dikenal atau dipakai pada barang yang secara umum telah dikenal dan dipakai pada barang yang diperdagangkan oleh seseorang atau badan, baik di wilayah Indonesia maupun di luar negeri."

Selanjutnya disebutkan pula bahwa: ${ }^{15}$

"Permohonan pendaftaran merek dalam Daftar Umum ditolak,apabila merek yang didaftarkan adalah :

a. merek terkenal milik orang lain atau milik badan lain;

b. merek yang mempunyai persamaan atau kemiripan, baik pada pokoknya maupun pada keseluruhannya dengan merek terkenal milik orang lain atau milik badan lain."

Hak eksklusif atas merek dapat berakhir bilamana merek tersebut dihapuskan atau dibatalkan. Dalam UU No. 15 Tahun 2001 penghapusan dan pembatalan merek diatur pada Pasal 61 s/d Pasal 72, sedangkan dalam UU No.20 Tahun 2016 diatur pada Pasal71 s/d Pasal 79.

Pembatalan merek adalah suatu prosedur yang ditempuh oleh salah satu pihak untuk mencari dan mengilangkan eksistensi pendaftaran dari suatu merek dari Daftar Umum Merek (DUM) atau membatalkan keabsahan hak berdasarkan sertifikat merek. ${ }^{16}$ Sedangkan penghapusan merek adalah ketika suatu merek terdaftar tidak digunakan sesuai dengan tujuan didaftarkannya merek tersebut. UU Merek mencegah agar pemilik merek

14 Lihat Pasal 1 Keputusan Menteri Kahakiman Republik Indonesia Nomor : M. 03-Hc.02.01 Tahun 1991Tentang Penolakan Permohonan Pendaftaran Merek Terkenal Atau Merek Yang Mirip Merek Terkenal Milik Orang Lain Atau Milik Badan Lain.

15 Lihat Pasal 2 ayat (1) huruf a dan b Keputusan Menteri Kahakiman Republik Indonesia Nomor : M. 03-Hc.02.01 Tahun 1991Tentang Penolakan Permohonan Pendaftaran Merek Terkenal Atau Merek Yang Mirip Merek Terkenal Milik Orang Lain Atau Milik Badan Lain.

16 Rahmi Jened, Hukum Merek (Trademark Law) Dalam Era Global \& Integrasi Ekonomi, Prenadamedia Group, Jakarta, 2015. Hlm. 291. 
tidak menyalahgunakan haknya. ${ }^{17}$ Perlindungan merek justru untuk memastikan bahwa pemegang merek harus menggunakan mereknya. Prinsip hukum bahwa merek dilindungi untuk digunakan, sehingga manakala suatu merek tidak digunakan tiga tahun berturutturut, maka negara dapat mengambil alih merek tersebut melalui tindakan penghapusan merek. $^{18}$

Alasan mengajukan penghapusan merek terdaftar, diatur dalam Pasal 61 ayat (2) UU No.15 Tahun 2001, yang berbunyi:

"Penghapusan pendaftaran Merek atas prakarsa Direktorat Jenderal dapat dilakukan jika:

a. Merek tidak digunakan selama 3 (tiga) tahun berturut-turut dalam perdagangan barang dan/atau jasa sejak tanggal pendaftaran atau pemakaian terakhir, kecuali apabila ada alasan yang dapat diterima oleh Direktorat Jenderal; atau

b. Merek digunakan untuk jenis barang/jasa yang tidak sesuai dengan jenis barang atau jasa yang dimohonkan pendaftaran, termasuk pemakaian Merek yang tidak sesuai dengan Merek yang terdaftar."

Sedangkan setelah berlakunya UU No. 20 Tahun 2016, alasan penghapusan merek diatur dalam Pasal 72 ayat (7) dan Pasal 74 ayat (1) UU No.20 Tahun 2016, yang berbunyi:

Pasal 72 ayat (7):

"Penghapusan Merek terdaftar atas prakarsa Menteri dapat dilakukan jika:

a. memiliki persamaan pada pokoknya dan/atau keseluruhannya dengan Indikasi Geografis;

b. bertentangan dengan ideologi negara, peraturan perundang-undangan, moralitas, agama, kesusilaan, dan ketertiban umum; atau

c. memiliki kesamaan pada keseluruhannya dengan ekspresi budaya tradisional, warisan budaya tak benda, atau nama atau logo yang sudah merupakan tradisi turun temurun.”

Pasal 74 ayat (1):

"Penghapusan Merek terdaftar dapat pula diajukan oleh pihak ketiga yang berkepentingan dalam bentuk gugatan ke Pengadilan Niaga dengan alasan Merek tersebut tidak digunakan selama (3) tahun berturut-turut dalam perdagangan barang dan/atau jasa sejak tanggal pendafataran atau pemakaian terakhir."

Adapun alasan diajukannya pembatalan merek, diatur di dalam Pasal 68 ayat (1) UU No.15 Tahun 2001, yang berbunyi: "Gugatan pembatalan pendaftaran Merek dapat diajukan oleh pihak yang berkepentingan berdasarkan alasan sebagaimana dimaksud dalam

17 Lihat Id. pada 303.

18 Ibid. 
Pasal 4, 5, dan 6." Namun saat ini, alasan diajukannya pembatalan merek diatur melalui Pasal 76 ayat (1) UU No.20 Tahun 2016, yaitu: “Gugatan pembatalan Merek terdaftar dapat diajukan oleh pihak yang berkepentingan berdasarkan alasan sebagaimana dalam Pasal 20 dan/atau Pasal 21.”

Akibat hukum, baik pembatalan maupun penghapusan merek terdaftar, adalah hilangnya hak eksklusif atas merek tersebut. Sehingga apabila suatu merek telah dihapus atau dibatalkan, merek tersebut dapat diajukan permohonan pendaftaran kembali oleh siapapun, karena merek tersebut dianggap tidak ada yang memiliki. Pemohon merek, baik pemilik semula maupun peohon baru harus mengajukan permohonan seesuai peraturan yang berlaku. Berdasarkan UUM2016, dan (EKS) prosedur pendaftaran merek harus melalui pemeriksaan administratif, dan pemeriksaan substanif sebelum mendapatkan sertifikat merek bila seluruh persyaratan dipenuhi. ${ }^{19}$

Kasus ini bermula ketika PT. Ratania Khatulistiwa, sebuah perusahaan yang didirikan tahun 1999 dan berdomisili di Surabaya, mengajukan permohonan permintaan pendaftaran merek "ikea" untuk kelas 20 dan kelas 21 pada 20 Desember 2013. Mengetahui bahwa Inter IKEA System sebagai pemilik merek "IKEA" untuk kelas barang yang sama sejak tahun 2010 dan 2006, PT. Ratania Khatulistiwa mengajukan gugatan penghapusan merek "IKEA" milik Inter IKEA System, pada 24 Desember 2013. Inter Ikea System BV merupakan sebuah perusahaan yang didirikan berdasarkan Undang-Undang Negara Belanda dan berdomisili di Amsterdam Belanda. Perusahaan ini didirikan pada tahun 1983, merupakan pemilik dari IKEA concept dan franchisor dari IKEA yang terseebar diseluruh dunia $^{20}$

Dasar gugatan PT. Ratania Khatulistiwa adalah Inter IKEA System tidak menggunakan merek "IKEA" selama 3 (tiga) tahun berturut-turut di Indonesia. Hal tersebut diketahui berdasarkan market survei yang dilakukan oleh sutu lembaga bernama Berlian Group Indonesia di 5 (lima) kota besar di Indonesia sejak November - Desember 2013. Petitum dari PT. Ratania Khatulistiwa diantaranya adalah menghapuskan merek "IKEA" milik Inter IKEA System dan menyatakan sah permohonan pendaftaran merek “ikea” milik PT. Ratania Khatulistiwa.Berikut petitum dari PT Ratania Khatulistiwa:

“1. Menerima dan mengabulkan gugatan PENGGUGAT untuk seluruhnya;

19 Lihat bagan mengenai alur permohonan pendaftaran merek di atas

20 Lihat Inter IKeA System BV pada http://franchisor.ikea.com/worldwide-ikea-franchisor/. Akses 8 Agustus 2017. 
2. Menyatakan PENGGUGAT sebagai Pihak Ketiga yang berkepentingan untuk mengajukan gugatan penghapusan pendafataran merek "IKEA" atas nama TERGUGAT Nomor Pendaftaran IDM000277901 tanggal pendaftaran 27 Oktober 2010 dan merek "IKEA" atas nama TERGUGAT Nomor Pendaftaran IDM000092006 tanggal pendaftaran 09 Oktober 2006;

3. Menyatakan Permohonan Permintaan Pendaftaran Merek "ikea" oleh PENGGUGAT untuk Kelas 20 yang telah diterima pendaftarannya oleh Direktorat Jenderal Hak Kekayaan Intelektual dengan Nomor Agenda D002013061337 tanggal 20 Desember 2013 adalah sah;

4. Menyatakan Permohonan Permintaan Pendaftaran Merek "ikea" oleh PENGGUGAT untuk Kelas 21 yang telah diterima pendaftarannya oleh Direktorat Jenderal Hak Kekayaan Intelektual dengan Nomor Agenda D002013061336 tanggal 20 Desember 2013 adalah sah;

5. Menyatakan merek "IKEA" yang terdaftar atas nama TERGUGAT dengan Nomor Pendaftaran IDM000277901 tanggal pendaftaran 27 Oktober 2010 untuk kelas barang/jasa 20, tidak digunakan selama 3 (tiga) tahun berturut-turut dalam perdagangan barang dan/atau jasa sejak tanggal pendaftarannya;

6. Menyatakan merek "IKEA" yang terdaftar atas nama TERGUGAT dengan Nomor Pendaftaran IDM000092006 tanggal pendaftaran 09 Oktober 2006 untuk kelas barang/jasa 21, tidak digunakan selama 3 (tiga) tahun berturut-turut dalam perdagangan barang dan/atau jasa sejak tanggal pendaftarannya;

7. Menyatakan penghapusan pendaftaran merek "IKEA" atas nama TERGUGAT dengan Nomor Pendaftaran IDM000277901 tanggal pendaftaran 27 Oktober 2010 untuk kelas barang/jasa 20 dari Daftar Umum Merek Direktorat Jenderal HAKI dengan segala akibat hukumnya;

8. Menyatakan penghapusan pendaftaran merek "IKEA" atas nama TERGUGAT dengan Nomor Pendaftaran IDM000092006 tanggal pendaftaran 09 Oktober 2006 untuk kelas barang/jasa 21 dari Daftar Umum Merek Direktorat Jenderal HAKI dengan segala akibat hukumnya;

9. Memerintahkan Panitera/Jurusita Pengadilan Niaga pada Pengadilan Negeri Jakarta Pusat atau pejabat lain yang ditunjuk agar mengirimkan 1 (satu) eksemplar copy putusan tersebut yang telah mempunyai kekuatan hukum tetap dan pasti dan memerintahkan kepada TURUT TERGUGAT untuk melaksanakan penghapusan Merek yang bersangkutan dari Daftar Umum Merek serta mengumumkannya dalam Berita Resmi Merek;

10.Menghukum TERGUGAT untuk membayar biaya perkara menurut hukum."

Didalam Surat Jawabannya, Inter IKEA System mengatakan bahwa sudah menggunakan merek "IKEA" sejak 1948. Hingga tahun 2006, Inter IKEA System memiliki setidaknya 237 toko yang tersebar di 34 negara dan telah mempekerjakan setidaknya 10.000 karyawan yang tersebar di 44 negara.Inter IKEA System menyampaikan 
bukti mengenai penggunaan merek IKEA melalui pemesanan barang-barang dengan mitra kerja nya di dalam bisnis. Bahwa diketahui pula, PT Ratania Khatulistiwa mengajukan Replik pada 23 Januari 2014 dan Inter IKEA System serta Direktorat Jeneral Hak Kekayaan Intelektual c.q. Direktorat Merek (Turut Tergugat) mengajukan Duplik pada 30 Januari 2014.

Majelis Hakim Pengadilan Niaga Jakarta Pusat, mempertimbangkan bahwa merek "IKEA" milik Inter IKEA System tidak digunakan selama 3 (tiga) tahun berturut-turut sejak tanggal pendaftarannya. Hal tersebut dibuktikan melalui hasil market survei yang dilakukan oleh Berlian Group Indonesia. Maka gugatan penghapusan merek "IKEA" milik Inter IKEA Sytem, berdasarkan Pasal 61 ayat (2) Undang-Undang No.15 Tahun 2001 tentang Merek, dikabulkan.

Pengadilan Niaga Jakarta Pusat melalui putusannya No.99/PDT.SUSMEREK/2013/PN.Niaga.Jkt.Pst., tertanggal 17 September 2014, mengabulkan gugatan PT. Ratania Khatulistiwa yakni menghapus merek "IKEA" milik Inter IKEA System, dan menyatakan Permohonan Permintaan Pendaftaran Merek "ikea" oleh PT. Ratania Khatulistiwa untuk kelas 20 dan kelas 21 yang telah diterima pendaftarannya oleh Direktorat Jenderal Hak Kekayaan Intelektual adalah sah. ${ }^{21}$

Terhadap putusan Pengadilan Niaga Jakarta Pusat tersebut, Inter IKEA System mengajukan kasasi. Secara ringkas, alasan-alasan yang mendasari Permohonan Kasasi adalah dikarenakan Judex Facti telah salah menerapkan atau melanggar hukum yang berlaku dan/atau tidak memberikan pertimbangan hukum yang cukup (onvoldoende gemotiveerd) dan/atau lalai memenuhi syarat-syarat yang diwajibkan peraturan perundangundangan yang mengancam kelalaian itu dengan batalnya putusan yang bersangkutan. ${ }^{22}$

Mahkamah Agung dalam pertimbangannya, tidak dapat membenarkan keberatankeberatan dari Pemohon Kasasi(Inter IKEA System) dan putusan Pengadilan Niaga Jakarta Pusat telah benar dan telah sesuai dengan Pasal 61 ayat (2) Undang-Undang No.15 Tahun 2001 tentang Merek.

Amar Putusan Mahkamah Agung No.264 K/Pdt.Sus-HKI/2015, tertanggal 12 Mei 2015 adalah menolak permohonan kasasi Inter IKEA System. Dengan kata lain, merek "IKEA" milik Inter IKEA System kelas 20 dan kelas 21 dihapus dan permohonan pendaftaran merek "ikea" milik PT. Ratania Khatulistiwa kelas 20 dan kelas 21

21 Lihat Putusan Pengadilan Niaga Jakarta Pusat No.99/PDT.SUS-MEREK/2013/PN.Niaga.Jkt.Pst. hlm. 83.

22 Putusan Mahkamah Agung No.264 K/Pdt.Sus-HKI/2015, Hlm. 19. 
disahkan.Terhadap putusan Mahkamah Agung tersebut, tidak diajukan upaya hukum lain sehingga sudah bersifat inkracht van gewijsde.

\section{ANALISIS TERHADAP PUTUSAN PENGADILAN YANG MENGHAPUSKAN MEREK}

Terhadap merek yang sudah tidak digunakan (non-use) selama 3(tiga) tahun berturutturut, dapat dimintakan penghapusan merek ke Pengadilan Niaga. Penghapusan tersebut dapat dilakukan oleh Direktorat Jenderal Kekayaan Intelektual, pemilik merek itu sendiri atau pihak ketiga, sesuai dengan Pasal 61 ayat $(1)^{23}$ dan Pasal $63^{24}$ UU No.15 Tahun 2001 (sekarang Pasal 72 ayat $(1)^{25}$ dan Pasal 74 ayat (1) ${ }^{26}$ UU No.20 Tahun 2016). Apabila Pengadilan Niaga memutus menghapus suatu merek, maka berakhir pula perlindungan atas hak eksklusif yang terdapat dalam merek tersebut, siapapun dapat mendaftarkan kembali merek yang telah dihapus, termasuk pemilik asal. Pendaftar tetap harus melakukan permohonan pendaftaran ke Direktorat Jenderal Merek dan Indikasi Geografis dan melewati proses pemeriksaan, karena yang berhak menentukan apakah suatu merek dapat didaftarkan dan memperoleh hak eksklusif adalah Direktorat Jenderal Kekayaan Intelektual c.q. Direktorat Jenderal Merek dan Indikasi Geografis.

Pada saat Direktorat Jenderal Merek dan Indikasi Geografis menerima permohonan pendaftaran merek yang memiliki persamaan pada pokoknya atau keseluruhannya dengan merek terkenal, berdasarkan Pasal 21 ayat (1) UU No.20 Tahun 2016 (dulu Pasal 6 ayat (1) UU No.15 Tahun 2001), maka permohonan tersebut harus ditolak.

Putusan Pengadilan Niaga Jakarta Pusat No.99/PDT.SUSMEREK/2013/PN.Niaga.Jkt.Pst. tertanggal 17 September 2014, sebagaimana yang telah dikuatkan melalui Putusan Mahkamah Agung No.264 K/Pdt.Sus-HKI/2015 tertanggal 12 Mei 2015 dan telah berkekuatan hukum tetap, penghapusan terhadap Merek "IKEA" karena sudah tidak digunakan selama 3 (tiga) tahun berturut-turut berdasarkan Pasal 61 ayat (2) UU No.15 Tahun 2001 adalah sudah tepat bilaPengadilan Niaga dapat membuktikan dari fakta yang ada bahwa Inter IKEA System tidak menggunaan mereknya sehingga secara normatif diatur dalam Undang-Undang No.20 Tahun 2016 Tentang Merek

23 Bunyi Pasal 61 ayat (1): "Penghapusan pendaftaran Merek dari Daftar Umum Merek dapat dilakukan atas prakarsa Direktorat Jenderal atau berdasarkan permohonan pemilik Merek yang bersangkutan."

24 Bunyi Pasal 63: "Penghapusan pendaftaran Merek berdasarkan alasan sebagaimana dimaksud dalam Pasal 61 ayat (2) huruf a dan huruf $b$ dapat pula diajukan oleh pihak ketiga dalam bentuk gugatan kepada Pengadilan Niaga."

25 Bunyi Pasal 72 ayat (1): "Penghapusan Merek terdaftar dapat diajukan oleh Pemilik Merek yang bersangkutan kepada Menteri."

26 Bunyi Pasal 74 ayat (1): "Penghapusan Merek terdaftar dapat pula diajukan oleh pihak ketigayang berkepentingan dalam bentuk gugatan ke Pengadilan Niaga dengan alasan Merek tersebut tidak digunakan selama 3 (tiga) tahun berturut-turut dalam perdagagan barang dan/atau jasa sejak tanggal pendaftaran atau pemakaian terakhir." 
dan Indikasi Geogarfis dan (eks) Undang-Undang No.15 Tahun 2001 Tentang Merek merek yang tidak digunakan dalam perdagangan selama 3 tahun kekutan hukumnya menjadi berakhir. Selanjutnya pemegang hak merek kehilangan hak eksklusif atas tanda yang semula dimiliki secara eksklusif. Berdasarkan aturan ini merek "IKEA" jika terbukti tidak digunakan selama 3 tahun secara berturut-turut oleh pemiliknya, pemilik merek yakni Inter IKEA System,BV tidak memiliki hak eksklusif sejak penghapusan memiliki kekuatan hukum.

Terlepas dari sifat putusan hakim sesuai prinsip Res Judicata Pro Veritate Habetur yakni a thing adjudged is regarded as truth $^{27}$ atau putusan hakim dianggap benar, penulis melakukan analisis mengenai dasar hukum dan alasan hakim memutuskan penghapusan merek IKEA.Bahwa benar secara normatif, jikatidak digunakan dalam perdagangan selama 3 tahun, merek akan menjadi hapus. Penghapusan bisa dimintakan oleh pihak ketiga dan diputuskan oleh pengadilan melalui guguatan ke pengadilan niaga. Sekalipun demikian, menurut penulis dalam memutus perkara tersebut hakim cenderung menerima begitu saja alat bukti dari penggugat. Tidak disebutkan alasan mengapa hakim mempercayai hasil survei pasar tersebut. Dalam kasus ini survei pasar dilakukan oleh lembaga survei berdasarkan pesanan penggugat, sehingga objektivitas dan keakuratannya diragukan. Dalam putusan hakim tidak menyebutkan alasan mengapa tidak menggunakan alat bukti yang diajukan tergugat. Alat bukti yang diajukan oleh tergugat merupakan bukti pemesanan barang yang menggunakan merek IKEA. Seharusnya hakim dapat lebih objektif dengan memutuskan untuk memerintahkan survei yang bersifat independen. Pada putusan Mahkamah Agung kasus ini terdapat disenting opinion. Isi disenting opinion pada pokokknya mengakui IKEA sebagai merek terkenal. Salah satu hakim dalam pertimbangannya mengatakan: ${ }^{28}$

"Bahwa Pemohon Kasasi/Tergugat dapat membuktikan dalilnya bahwa Merek IKEA Tergugat telah terdaftar secara sah dan merupkan merek terkenal yang harus dilindungi dan tidak terdapat alasan-alasan untuk dihapus, secara kasat mata toko-toko milik Tergugat yang menjual produk-produknya tersebar dan di Indonesia toko resmi IKEA a quoyang cukup besar berada di Jalan alam Sutera Tangerang/Banten, sehingga dengan demikian Pasal 61 ayat (2) huruf a Undang-Undang Nomor 15 tahun 2001 tentang Merek tidak dapat diterapkan."

Terhadap putusan hakim yang menyatakan merek IKEA hapus karena tidak digunakan dan meminta kepada turut tergugat untuk mencoret IKEA dari pendaftaran

27 Lihat Res Judicata Pro veritate habetur Ballentine's Law Dictionary, pada m.openjurist.org, akses 9 Agustus 2017.

28 Putusan Mahkamah Agung R.I No.264 K/Pdt.Sus-HKI/2015 Hlm. 51. 
berakibat tidak ada lagi yang memiliki hak eksklusif terhadap merek IKEA. Siapa saja dapat mengajukan permohonan atas merek yang sudah tercoret. Hakim juga menyatakan bahwa permohonan merek yang diajukan oleh PT Ratania Khatulistiwa sah, sehingga Direktorat Jenderal Kekayaan Intelektual wajib untuk menerima permohonan tersebut untuk diproses sesuai prosedur yang berlaku. Prosedur pendaftaran merek harus melalui tahap tahap pemeriksaan administratif dan substantif. Kalau dikabulkan baru lah pemohon menjadi pemegang merek dan memiliki hak eksklusif. Jika PT Ratania Khatulistiwa gagal mendapatkan hak merek, Inter IKEA System dapat mendaftarakan kembali merek "IKEA" ke Direktorat Jenderal Merek dan Indikasi Geografis dengan mengajukan permohonan pendaftaran merek.

Secara normatif, jika suatu merek dihapuskan dan pemilik merek yang dihapuskan mereknya masihengharapkan hak eksklusif atas merek tersebut, maka pemilik merek lama harus mengajukan permohonan pendaftaran merek, melalui prosedur pendaftaran merek, yakni pemeriksaan sadministratif, substantif dan keputusan apakah diterima atau tidak. Bila ada pihak lain yang telah mengajukan permohonan merek yang sama terlebih dahulu, maka pemilik merek lama berhak untuk menagjukan keberatan.Bila keberatan diabaikan dan negara mengabulkan permohonan merekbagi pemohon baru, maka pemilik merek lama masih memiliki upaya hukum untuk mengajuan pembatalan mereka. Pemilik merek lama masih memiliki upaya hukum kasasi dan peninjauan kembali jika putusan pengadilan niaga tidak sesuai dengan yang ia harapkan.

Dalam hal kasus sengketa merek Ikea, meski merek IKEA milik Inter IKEA Sysem sudah hapus, putusan hakim tidak menghilangkan sifat terkenal dari merek IKEA. Oleh karena itu Inter IKEA System dapat mengajukan keberatan dengan membuktikan bahwa penggunaan merek ikea atas dasar itikad tidak baikserta memperlihatkan bahwa IKEA merupakan merek terkenal. Pemeriksa merek harus memperhatikan sanggahan tersebut. Dapat terjadi, pemeriksa merek berpendapat bahwa IKEA adalah merek terkenal sehingga berdasarkan Pasal 21 ayat (1) UU No 20 tahun 2016 (eks Pasal 6 ayat (1) huruf b UU No.15 tahun 2001) merek ikea tidak bisa digunakan oleh pihak lain dalam hal ini PT Ratania Khatulistiwa. Namun sebaliknya bisa terjadi pemeriksa merek berpendapat bahwa merek ikea yang digunakan oleh Inter IKEA system tidak termasuk merek terkenal (meski kemungkinan kecil, karena merek IKEA sudah dipasarkan secara global dan hambatan yang tentu dialami oleh PT Ratania Khatulistiwa saat mengekspor merek ikea untuk produk peralatan rumah tangga kepada mitra bisnis di luar negeri) 


\section{PENUTUP}

\section{Simpulan}

a. Berdasarkan putusan pengadilan merek Ikea yang dimiliki oleh Inter IKEA System dihapuskan. Alasan penghapusan dilakukan karena menurut pertimbangan hakim merek tersebut tidak digunakan dalam jangka waktu 3 tahun Sesuai sitem pendafaran merek di Indonesia, maka hak eksklusif yang dimiliki oleh Inter IKEA sytem juga berakir. Hal ini tidak otomatif menyebabkan PT Ratania Khatulistiwa memiliki hak eksklusif atas ikea menggantikan Inter IKEA System. Putusan hanya berakibat PT ratania berhak untuk mengajukan permohonan merek. Terhadap permohonan tersebut harus melewati persyaratan admnistratif dan substantif untuk dapat mendapatkan hak eksklusif. Pemilik merek lama dapat mengajukan keberatan atas permohonan tersebut . Jika keberatan gagal, pemilik merek lama masih memiliki hak untuk mengajukan pembatalan merek.

b. Jika suatu merek dihapuskan dan pemilik merek yang dihapuskan mereknya masih mengharapkan hak eksklusidf atas merek tersebut, pemilik merek lama harus mengajukan permohonan pendaaftaran merek dan melalui prosedur pendaftaran merek, yakni pemeriksaan administratif , substantif dan keputusan apakah diterima atau tidak. Bila ada pihak lain yang telah mengajukan permohonan merek yang sama terlebih dahulu, maka yang pemilik merek lama berhak mengajukan keberatan. Bila keberatan diabaikan dan negara mengabulkan permohonan merek merek, maka eks pemilik merek masih memiliki upaya hukum untuk mengajuan pembatalan. Terhadap putusan Pengadilan Niaga masih dapat dilakukan upaya hukum Kasasi dan Peninjauan kembali.

\section{Saran}

Hak eksklusif yang dimiliki pemegang hak merek memperlihatkan kekuatan dari sertifikat merek. Selain memiliki sertifikat, pemegang merek wajib menggunakan merek yang dimiliki dalam perdagangan barang/jasa. Penggunaan merek mencegah penghapusan merek yang menghilangkan hak eksklusif pemegang hak merek. Sengketa di bidang Hukum Kekayaan termasuk merek menguras waktu dan biaya pebisnis dalam menjalankan kegiatasnnya. Oleh karena itu untuk mencegah sengketa merek, sebaiknya 
para pemilik merek mendaftarakan erek yang dimilliki sehingga memegang hak eksklusif atas merek yang dimilliki. Merek juga harus digunakan untuk mencegah penghapusan merek. melakukan pendaftara didaftarkan dan digunakan. Lebih mudah murah dan prkatis meakukan pendaftaran dan menggunakan merek yang dimiliki dari pada tidak melakukan satu atau keduanya. Kasus memperlihatkan betapa panjang jalan yg harus ditempuh oleh InterIKEA system BV untuk mempertahankan merek yang semula dimiliki namun menjadi hapus karena menurut putusan hakim tidak digunakan.

\section{DAFTAR PUSTAKA}

\section{BUKU}

Colston, Catherine,Principles of Intelectual Property, Cavendish Publishing Limited, Lodon.Sydney. 1999

Djumhana, Muhammad \& Djubaedillah, Hak Milik Intelektual: Sejarah, Teori, dan Praktiknya di Indonesia, Citra Aditya Bakti, Bandung 2014.

Johnny Ibrahim, Teori dan metodologi Penelitian Hukum normatif, Bayumedia Publishing, Malang, 2013

Rahmi Jened, Hukum Merek (Trademark Law) Dalam Era Global \& Integrasi Ekonomi, Prenadamedia Group, Jakarta. 2015,

Lindsey, Tim, et al,Hak Kekayaan Intelektual, Alumni, Bandung. 2004.

Margono, Suyud, Hak Milik Industri Pengaturan dan Praktik di Indonesia, Ghalia Indonesia, Bogor.2011.

Nazir, M., Metode Penelitian, Ghalia Indonesia, Jakarta.1998.

Saidin, OK,Aspek Hukum Hak Kekayaan Intelektual (Intellectual Property Rights), Rajawali Pers, Jakarta.2015.

Schechter, Roger E. \& Thomas, John R.,Intellectual Property The Law of Copyrights, Patents and Trademarks, Thomson USA. 2003.

Soerjono Soekanto, dan Sri Mamudji,Penelitian Hukum Normatif: Suatu Tinjauan Singkat, Rajawali Pers, Jakarta.2001.

Adrian Sutedi,Hak Atas Kekayaan Intelektual, Sinar Grafika, Jakarta.2013.

Sudaryat,Hak Kekayaan Intelektual, OASE Media, Bandung.2010,.

World Intellectual Property Organization, Memahami Hak Kekayaan Intelektual, Direktorat Jenderal Hak Kekayaan Intelektual, penerj., World Intellectual Property Organization, Geneva. 


\section{JURNAL}

Agung Sujatmiko, Pembajakan Merek Merusak Ekonomi Nasional, Jurnal Hukum Pro Justitia, Vol. 25.2007.

, Sifat dan Manfaat Perjanjian Lisensi Merek Terkenal, Jurnal Law Review, Vol. X. 2011.

\section{ARTIKEL/INFORMASI TERKAIT}

Kamus Besar Bahasa Indonesia http://kbbi.web.id/merek.

Direktorat Jendral Kekayaan Intelektual Republik Indonesia http://www.dgip.go.id/tentang-kami/struktur-organisasi-djki

----------------, http://skm.dgip.go.id/index.php/skm/detailkelas/20 http://skm.dgip.go.id/index.php/skm/detailkelas/21

Inter IKeA System BV pada http://franchisor.ikea.com/worldwide-ikea-franchisor/. Akses 8 Agustus 2017

Res Judicata Pro veritate habetur Ballentine's Law Dictionary, pada m.openjurist.org, akses 9 Agustus 2017

\section{PERATURAN PERUNDANG-UNDANGAN TERKAIT}

Indonesia. Undang-Undang R.I., No. 15 Tahun 2001, Merek, L.N.R.I. Tahun 2001 No. 110.

Indonesia. Undang-Undang R.I., No. 20 Tahun 2016, Merek dan Indikasi Geografis, L.N.R.I. Tahun 2016 No. 252.

Indonesia. Keputusan Menteri Kehakiman, Nomor 03-HC.02.01 Tahun 1991 tentang Penolakan Permohonan Pendaftaran Merek Terkenal atau Merek yang Mirip Merek Terkenal Milik Orang Lain atau Milik Badan Lain

\section{PUTUSAN BADAN PERADILAN}

Mahkamah Agung Republik Indonesia, No. 264 K/Pdt.Sus-HKI/2015, Inter Ikea System B.V. vs PT Ratania khatulistiwa, 2016.

Pengadilan Niaga Jakarta Pusat, No. 99/PDT.SUS/MEREK/2013/PN.Niaga.Jkt.Pst, PT Ratania Khatulistiwa vs Inter Ikea System B.V., 2016. 